\title{
Serogroup $\mathrm{F}$ strains of Clostridium difficile produce toxin $B$ but not toxin $A$
}

\author{
C. DEPITRE, M. DELMEE*, V. AVESANI*, R. L'HARIDON $\dagger$, A. ROELS, M. POPOFF $\$$ and \\ G. CORTHIER
}

UEPSD, FBI, INRA, 78352 Jouy en Josas, France, "Unité de Microbiologie, Université catholique de Louvain, Avenue Hippocrate 54, B 1200 Bruxelles, Belgique, †Laboratoire de Virologie et d'Immunologie Moléculaire, INRA, 78352 Jouy en Josas and $\ddagger$ Unité de Toxines Microbiennes, Institut Pasteur, 25 rue du Dr Roux, 75724 Paris, France

\begin{abstract}
Summary. Most toxigenic strains of Clostridium difficile produce two toxins: an enterotoxin (toxin A) and a cytotoxin (toxin B). Only one strain (strain 8864) has been reported to produce toxin B but no toxin A. Serogroup F strains (44) of $C$. difficile, often isolated from asymptomatic infants, have been examined for toxin production. These strains, which were from distinct geographical and clinical sources, did not produce any detectable toxin A in vitro when examined in three distinct immunoassays. Nevertheless, all the strains produced a cytotoxin. Immunological differences between the cytotoxin of the serogroup F strains and that produced by $C$. difficile strain VPI 10463 (serogroup G) were demonstrated with monoclonal antibodies specific for either the toxin B produced by C. difficile strain VPI 10463 or $C$. sordellii lethal toxin (LT). Polymerase chain reaction amplification with primers derived from C. difficile strain VPI 10463 toxin A and B genes showed that serogroup F strains seem to possess a toxin B gene homologous with that of strain VPI 10463 and at least fragments of the toxin A gene. When axenic mice were inoculated with serogroup F strains, the animals survived; they did not develop diarrhoea and no toxin A could be detected in their faeces. However, cytotoxin was detected. Furthermore, these mice were protected against subsequent challenge with the otherwise lethally toxigenic $C$. difficile strain VPI 10463. The serogroup F strains appeared to be homogeneous and distinct from other $C$. difficile strains with regard to toxin production.
\end{abstract}

\section{Introduction}

The aetiological role of Clostridium difficile in pseudomembranous colitis and antibiotic-associated diarrhoea has been clearly demonstrated. ${ }^{1.2}$ Pathogenicity appears to be due mainly to the production of two toxins--an enterotoxin (toxin A) and a cytotoxin (toxin B) ${ }^{3-6}$ However, there is considerable interstrain variation in the amounts of toxins produced in vitro ${ }^{78}$ Most workers agree that there is a link between toxin A and B production, and this is in agreement with the linkage of these toxin genes on the chromosome $^{9.10}$ There has been only one strain (strain 8864 ) identified previously as toxin $\mathrm{A}^{-}, \mathrm{B}^{+} .{ }^{11,12}$

Typing methods based on polyacrylamide gel electrophoresis (PAGE) and serogrouping have been used recently in conjunction, yielding a classification of 21 serogroups of $C$. difficile. ${ }^{13-18}$ Some serogroups are homogeneous with regard to toxin production but others include toxigenic and non-toxigenic strains. ${ }^{8}$ All strains of serogroup $F$ produced cytotoxin, but toxin
A production was not determined. ${ }^{15}$ Strains from this serogroup were mainly isolated from asymptomatic infants. ${ }^{19}$ In clindamycin-treated hamsters, Delmée et $a l .{ }^{20}$ compared the pathological effect of 10 different $C$. difficile serogroups, and found that the reference strain of serogroup F (ATCC 43598) was the only toxigenic strain examined that did not induce colitis, despite producing detectable cytotoxin in the intestine. In this study, serogroup $F$ strains were further characterised with regard to production of toxin A, presence of the toxin A gene, and pathogenicity.

\section{Materials and methods}

\section{Strains of C. difficile}

The 44 serogroup $F$ strains were isolated from patients' stools between 1983 and 1991 on CCFA (cycloserin-cefoxitin-fructose-agar) medium and identified by colony morphology and gas-liquid chromatography. ${ }^{14}$ Their origins are indicated in table $I$. Inclusion of multiple isolates from clusters of infection was avoided. The control strains of $C$. difficile were: 
Table I. Origin of serogroup F strains

\begin{tabular}{|c|c|c|c|c|c|c|c|c|c|}
\hline \multirow{2}{*}{ Origin } & \multicolumn{5}{|c|}{ Age of patients (years) } & \multicolumn{4}{|c|}{ Stool consistency } \\
\hline & $<1$ & $1-2$ & $2-12$ & $>20$ & Other* & Solid & Soft & Liquid & ND* \\
\hline $\begin{array}{l}\text { St Luc Hospital, } \\
\text { Bruxelles (11 units) }\end{array}$ & 18 & 2 & 2 & 4 & 0 & 1 & 16 & 1 & 8 \\
\hline $\begin{array}{l}\text { Outpatients (St Luc } \\
\text { Hospital) }\end{array}$ & 4 & 3 & 0 & 4 & 0 & 0 & 9 & 2 & 0 \\
\hline $\begin{array}{l}\text { Other hospitals (Belgium } \\
\text { and elsewhere) } \dagger\end{array}$ & 3 & 1 & 1 & 1 & 1 & 0 & 4 & 0 & 3 \\
\hline
\end{tabular}

No serogroup $\mathrm{F}$ strains were isolated from patients aged 12-20 years.

*Origin not determined.

†Includes ATCC 43598.

VPI 10463, ATCC nos. 43594, 43596, 43598 (a serogroup F strain not tested before), 43599 and 43600 , and CD 196 (Pasteur Institute). C. sordellii strain IP 82 (Pasteur Institute) was used as negative control in polymerase chain reaction (PCR) tests; it produces the haemorrhagic and lethal toxins (HT and LT).

\section{Serogrouping}

The serogroup of each strain was determined by slide agglutination with rabbit antisera by the method described by Delmée et al. ${ }^{14}$ and confirmed by PAGE as described previously. ${ }^{15}$

\section{Monoclonal and polyclonal antibodies}

Monoclonal (MAb) and polyclonal antibodies against toxin A and toxin B of strain VPI 10463 were produced as described previously. ${ }^{21-23}$ MAbs against C. sordellii lethal toxin (LT) were prepared after immunisation of BALB/c Jackson mice with purified toxin $\mathrm{LT}{ }^{24}$ Fusion was performed with $\mathrm{SP}_{2} \mathrm{O}$ myeloma cells. ${ }^{21}$ Two MAbs (N1 and J2) were obtained and characterised in ELISA with pure $C$. sordellii toxin LT. The ELISA titres against toxin LT were $5 \cdot 2 \log _{10}$ and $6.2 \log _{10}$, respectively. Both were $\operatorname{IgG}_{1}, \kappa$ antibodies and cross-reacted with purified $C$. difficile toxin B from strain VPI 10463 in ELISA and immunoblotting.

\section{Detection of $C$. difficile toxins}

Toxin A detection with ELISA. Three distinct sandwich ELISAs were employed. In the first, MAbs and polyclonal antibodies were prepared against toxin A. ${ }^{21,23}$ Microtitration plates (Immulon Type 1, Dynatech) were coated with the mouse MAb (C11) diluted 1 in 3000 in sodium bicarbonate buffer and incubated overnight at $4^{\circ} \mathrm{C}$. Plates were washed with phosphatebuffered saline containing Tween $200 \cdot 1 \%$ w/v (PBS$\mathrm{T})$ and incubated for $90 \mathrm{~min}$ at $37^{\circ} \mathrm{C}$ with three-fold serial dilutions of the toxin-containing sample in PBS$\mathrm{T}$ supplemented with Soybean Trypsin Inhibitor (Sigma) $1 \mathrm{mg} / \mathrm{ml}$. After further washing, rabbit poly- clonal antiserum against toxin $\mathrm{A}$ was added ( 1 in 2000 dilution) and the plates were incubated at $37^{\circ} \mathrm{C}$ for $2 \mathrm{~h}$. They were washed again and incubated with an alkaline phosphatase-labelled anti-rabbit IgG (Sigma) diluted 1 in 2000 in PBS-T for $90 \mathrm{~min}$. After a final wash, enzyme substrate ( $p$-nitrophenyl phosphate, Sigma 104 tablets) in ethanolamine buffer ( $\mathrm{pH} 9.8$ ) was added and the absorbance at $405 \mathrm{~nm}$ was measured after incubation for $1 \mathrm{~h}$ at $37^{\circ} \mathrm{C}$. Toxin $\mathrm{A}$ concentration was estimated from a standard curve and expressed as $\log _{10} \mathrm{ng} / \mathrm{ml}$ (culture medium) or $\log _{10} \mathrm{ng} / \mathrm{g}$ (faeces). ${ }^{23}$ The detection limit was $0 \cdot 1 \mathrm{ng} / \mathrm{ml}$.

The second ELISA with two polyclonal antisera to toxin A from pig and rabbit has been described previously. ${ }^{23}$ The third ELISA was a commercial system (PREMIER- $C$. difficile Toxin A EIA, Meridian Diagnostics Inc.) with MAbs and polyclonal antibodies to toxin $\mathrm{A}^{25}$

Toxin B detection. Cytotoxic activity was measured on CHO-K1 cells after three-fold serial dilution of samples. ${ }^{7}$ It was expressed as $\log _{10}$ titre corresponding to the highest dilution causing $100 \%$ cell rounding. Neutralisation of cytotoxicity was examined with an anti- $C$. sordellii and an anti- $C$. difficile serum (Wellcome, Belgium).

\section{Immunological assays for toxin $B$}

Four MAbs (two raised against $C$. difficile strain VPI 10463 toxin B, and two raised against $C$. sordellii LT) were used to further characterise the cytotoxins produced by serogroup $F$ strains in comparison with that produced by strain VPI 10463. Wells of microtitration plates (Immulon type 1, Dynatech) were coated for $2 \mathrm{~h}$ at $37^{\circ} \mathrm{C}$ with serogroup $\mathrm{F}$ strain culture supernates obtained after culture for 4 days in dialysis flassks ${ }^{6}$ and two-fold serially diluted in carbonate buffer (pH 9.6). The wells were washed and 1 in 100 dilutions of ascites fluid containing antitoxin $\mathrm{B}$ or antitoxin $\mathrm{LT}$ were added. After incubation for $1 \mathrm{~h}$ at $37^{\circ} \mathrm{C}$, wells were washed, a 1 in 1000 dilution of anti-mouse peroxidase conjugate was added and the plates were incubated for $2 \mathrm{~h}$ at $37^{\circ} \mathrm{C}$. The wells were washed and $0.1 \mathrm{ml}$ of tetramethylbenzidine substrate (TMB kit, 


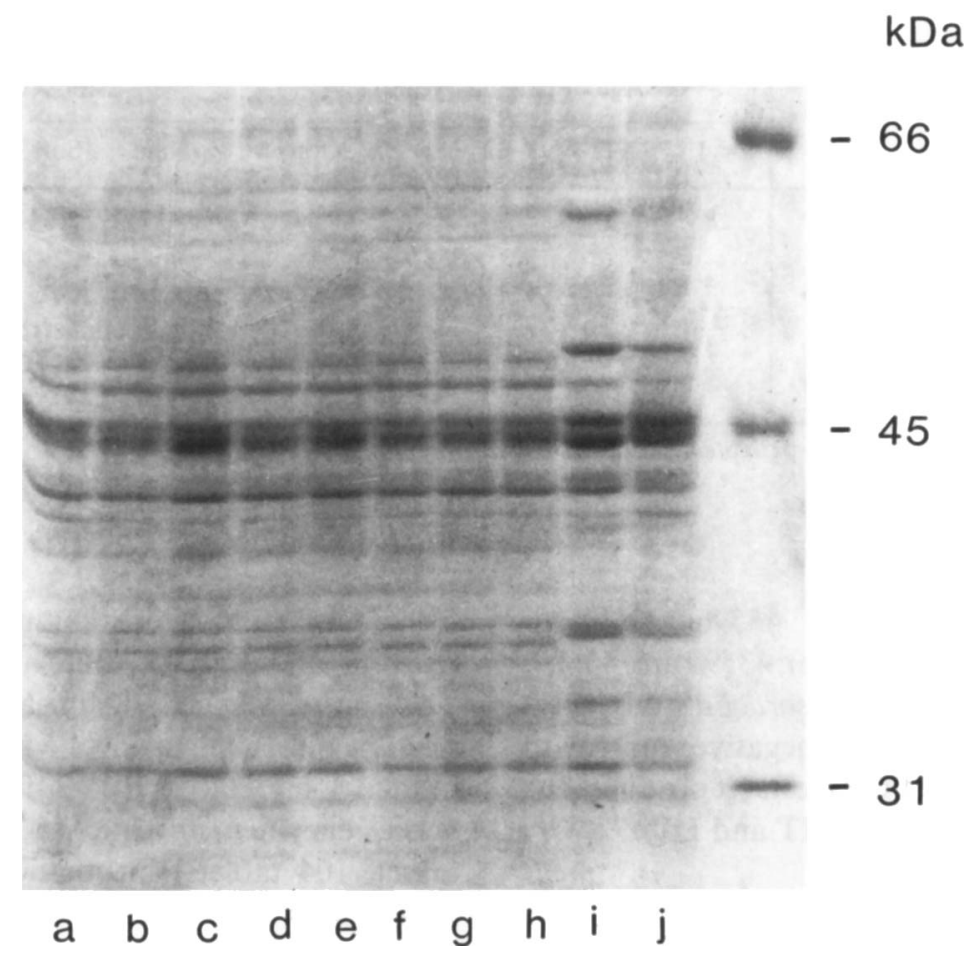

Fig. 1. SDS-PAGE profiles of serogroup F strains (lanes A-H) compared to serogroup G stains (I and $\mathbf{J}$ ). The distinctive band shift from $36.5 \mathrm{kDa}$ (serogroup F) to $37 \mathrm{kDa}$ (serogroup G) is clearly visible. Lanes: A, 11723; B, 11833; C, 22484; D, 20174; E, 18933; F, 15878; G, $11212 ;$ H, ATCC 43598; I, VPI 10463; J, ATCC 43599.

Dynatech) was added to each well. Reactions were stopped by the addition of $2 \mathrm{~N}$ sulphuric acid and the optical densities were measured at $450 \mathrm{~nm}$. All washes were with PBS-T.

\section{$D N A$ amplification by polymerase chain reaction $(P C R)$}

Purified DNA (100 ng) was amplified by PCR with synthetic oligonucleotides (table IV) derived from toxin A and B gene nucleotide sequences, respectively. ${ }^{9.26,27}$ DNA amplification was performed in a total volume of $100 \mu \mathrm{l}$ of $10 \mathrm{mM}$ Tris $\mathrm{HCl}(\mathrm{pH} \mathrm{8.3)}$ containing $50 \mathrm{mM} \mathrm{KCl}, 4 \mathrm{mM} \mathrm{MgCl}_{2}$, bovine serum albumin $0 \cdot 1 \%, 100 \mu \mathrm{M}$ deoxynucleotide triphosphates, $10 \mathrm{~mm} 2$-mercaptoethanol, $25 \mathrm{pmol}$ of each primer, and $2.5 \mathrm{U}$ of Taq polymerase (Amersham). Reaction mixtures were denaturated initially at $95^{\circ} \mathrm{C}$ for $2 \mathrm{~min}$, then subjected to 30 cycles of denaturation (20s at $\left.95^{\circ} \mathrm{C}\right)$, annealing $\left(20 \mathrm{~s}\right.$ at $68^{\circ} \mathrm{C}$ for toxin $\mathrm{B}$ primers or $52^{\circ} \mathrm{C}$ for toxin A primers), and extension $\left(20 \mathrm{~s}\right.$ at $\left.72^{\circ} \mathrm{C}\right)$ in a Prem III thermal cycler (Flobio). Amplification products were visualised by ethidium bromide staining after agarose $1 \%$ gel electrophoresis.

\section{Animal experiments}

Axenic $\mathrm{C} 3 \mathrm{He} / \mathrm{J}$ mice were reared in a Trexler isolator fitted with a rapid transfer system (La Calhène, Vélizy, France) and fed with a rodent diet (RO3-40, UAR, Villemoisson, France). All materials introduced into the isolator had been sterilised by irradiation or heating.

Mice received $0.5 \mathrm{ml}$ of a $24-\mathrm{h}$ culture of $C$. difficile $\left(10^{8} \mathrm{cfu} / \mathrm{ml}\right)$ by the orogastric route. Population levels in faeces were measured by viable counts on Brain Heart Infusion Agar (BHI, Difco). Faecal toxin levels were estimated as described above. For protection experiments, mice received the highly toxigenic strain VPI 10463 by the orogastric route, 11 days after inoculation of the serogroup $F$ strain. After toxin estimation, and viable counts, $C$. difficile colonies from the lowest dilution giving isolated colonies were serotyped by the method described above. This allowed estimation of the relative counts of the serogroup F, and the serogroup G VPI 10463 strains.

\section{Results}

The $44 C$. difficile strains were identified as members of serogroup $F$ in slide agglutination and PAGE. Fig. 1 contrasts typical serogroup F PAGE patterns with those of reference strains belonging to serogroup $G$. Table I shows their origins; most were isolated from asymptomatic infants and a few were from adults. Many were isolated in Belgium (one from Poland) but at different times in various hospitals. They were from 11 out-patients and 33 in-patients. The latter were from seven different hospitals and 17 different units, and were, therefore, epidemiologically distinct. Only three of the faecal samples from which they were isolated were liquid, and all three were from children with mild diarrhoea. 
Table II. In-vitro toxin production of $C$. difficile serogroup F strains compared to reference strains of various serogroups

\begin{tabular}{|c|c|c|c|}
\hline $\begin{array}{l}\text { C. difficile } \\
\text { serogroup }\end{array}$ & $\begin{array}{l}\text { Number of } \\
\text { strains }\end{array}$ & $\begin{array}{c}\text { Toxin } A^{*} \\
\left(\log _{10} \mathrm{ng} / \mathrm{ml}\right)\end{array}$ & $\begin{array}{c}\text { Toxin B } \\
\left(\log _{10} \text { titre }\right)\end{array}$ \\
\hline $\mathrm{F}$ & 1 & 0 & $2 \cdot 1$ \\
\hline $\mathrm{F}$ & 7 & 0 & $2 \cdot 6$ \\
\hline $\mathrm{F}$ & 1 & 0 & $2 \cdot 8$ \\
\hline $\mathrm{F}$ & 23 & 0 & $3 \cdot 1$ \\
\hline $\mathrm{F}$ & 3 & 0 & $3 \cdot 3$ \\
\hline $\mathrm{F}$ & 4 & 0 & 3.5 \\
\hline $\mathrm{F}$ & 1 & 0 & $3 \cdot 7$ \\
\hline $\mathrm{F}$ & 3 & 0 & 4 \\
\hline $\mathrm{F}$ & 1 & 0 & $4 \cdot 5$ \\
\hline A & ATCC 43594 & 1.1 SEM 0.3 & 2.6 SEM 0.4 \\
\hline $\mathrm{C}$ & ATCC 43596 & 0.5 SEM 0.2 & 1.8 SEM 0.4 \\
\hline G & ATCC 43599 & 1.6 SEM 0.2 & 4.5 SEM 0.5 \\
\hline G & VPI 10463 & 3.2 SEM 0.3 & 5.5 SEM 0.4 \\
\hline $\mathrm{H}$ & ATCC 43600 & 0.6 SEM 0.3 & 2.6 SEM 0.3 \\
\hline
\end{tabular}

$*_{0}$ indicates levels $<0.1 \mathrm{ng} / \mathrm{ml}$.

All 44 strains produced cytotoxin at levels of $2 \cdot 1-4 \cdot 5 \log _{10}$ (average 3.1 $\log _{10}$ ) (table II). Reference strains (lethal for hamster ${ }^{20}$ or gnotobiotic mice ${ }^{7}$ ) produce similar levels of toxin B, except the VPI strain which is known to produce high levels of toxin. The cytotoxin was neutralised by both anti- $C$. difficile and anti- $C$. sordellii sera. Toxin A production was not detected in any of the three ELISAs (table II) for any serogroup $F$ strain. However, the results with reference strains were all positive for toxin $\mathrm{A}$ in these tests.

Toxin production is enhanced by dialysis culture. ${ }^{5,6}$ C. difficile strain VPI 10463 and three serogroup F strains (chosen for their high level of toxin B production) were grown in dialysis culture (table III). Toxin A production by strain VPI 10463 was increased. However, no toxin A was detected in serogroup $\mathrm{F}$ dialysis cultures.

Immunological epitopes of the toxin B produced were investigated by reaction with four distinct MAbs. The toxin B produced by strain VPI 10463 reacted strongly with the two MAbs raised against $C$. difficile toxin B and those raised against $C$. sordellii LT. By contrast, the toxin B produced by serogroup $F$ strains did not react with MAbs raised against $C$. difficile toxin B but reacted with one of the MAbs specific for C. sordellii LT (table III).

PCR confirmed the presence of a toxin B gene homologous to that of $C$. difficile strain VPI 10463 in the serogroup F strains, at least for the DNA region corresponding to the primers P89-P90 (table IV and

Table III. Biological activity and immunological analysis of toxins produced in dialysis culture by three $C$. difficile serogroup $F$ strains and a reference strain of serogroup $G$

\begin{tabular}{|c|c|c|c|c|c|c|c|}
\hline \multirow{3}{*}{$\begin{array}{l}\text { Strain } \\
\text { no. }\end{array}$} & \multirow{3}{*}{ Serogroup } & \multirow{3}{*}{$\begin{array}{c}\text { Toxin } A^{*} \\
\left(\log _{10} \mathrm{ng} / \mathrm{ml}\right)\end{array}$} & \multirow{3}{*}{$\begin{array}{c}\text { Toxin B } \\
\text { cytotoxicity } \\
\left(\log _{10} \text { titre) }\right.\end{array}$} & \multicolumn{4}{|c|}{$\begin{array}{l}\text { Optical densities } \nmid \text { obtained with } \\
\text { MAbs raised against }\end{array}$} \\
\hline & & & & \multicolumn{2}{|c|}{ C. difficile toxin B } & \multicolumn{2}{|c|}{ C. sordellii LT } \\
\hline & & & & W34 & F18 & NI & $\mathrm{J} 2$ \\
\hline 5270 & $\mathrm{~F}$ & $0 \ddagger$ & 4.2 SEM 0.4 & $<0.1$ & $<0.1$ & $0 \cdot 24$ SEM $0 \cdot 1$ & $<0.1$ \\
\hline 37101 & F & $0 \neq$ & 4.5 SEM 0.4 & $<0.1$ & $<0.1$ & 0.64 SEM 0.2 & $<0.1$ \\
\hline ATCC 43598 & F & $0 \ddagger$ & 5.4 SEM 0.3 & $<0.1$ & $<0 \cdot 1$ & 0.83 SEM 0.2 & $<0.1$ \\
\hline VPI 10463 & $\mathrm{G}$ & 4.1 SEM 0.3 & 6.5 SEM 0.4 & 1.64 SEM 0.1 & 1.70 SEM 0.2 & 1.14 SEM 0.2 & 0.97 SEM 0.1 \\
\hline
\end{tabular}

*Toxin A concentration was determined with a sandwich ELISA with MAb C11 and rabbit polyclonal antiserum.

$\dagger$ The optical density at $450 \mathrm{~nm}$ represents the reaction obtained after coating of microtitration plates with culture supernate, incubation with MAbs and reaction (in two steps) with an anti-mouse peroxidase conjugate and the enzyme substrate (TMB).

$\ddagger$ Below the detection limit $(0.1 \mathrm{ng} / \mathrm{ml})$.

Table IV. Primers used in PCR amplification

\begin{tabular}{|c|c|c|c|}
\hline Primers & Positions & Location & $\begin{array}{l}\text { Sizes (bp) of } \\
\text { amplification } \\
\text { products }\end{array}$ \\
\hline $\begin{array}{l}\text { P } 32^{5 /}{ }^{5} \text { GAGTTAATAAAACTCGCATAGC } \\
\text { P66 }\end{array}$ & $\begin{array}{c}1303-1326 \\
1753-1735 \\
\text { (complementary } \\
\text { strand) }\end{array}$ & Toxin A gene $\mathrm{e}^{25}$ & 450 \\
\hline $\mathrm{P} 60^{5 \prime}$ ATAAACTATAGCCTGACCTTCTATG ${ }^{3 \prime}$ & $\begin{array}{l}7047-7023 \\
\text { (complementary } \\
\text { strand) }\end{array}$ & Toxin A gene ${ }^{25}$ & 380 \\
\hline 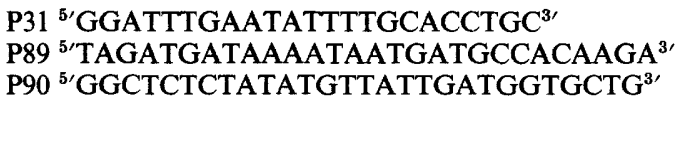 & $\begin{array}{c}\text { 7384-7406 } \\
3814-3841 \\
3991-3964 \\
\text { (complementary } \\
\text { strand) }\end{array}$ & Toxin B gene ${ }^{9}$ & 150 \\
\hline
\end{tabular}


a

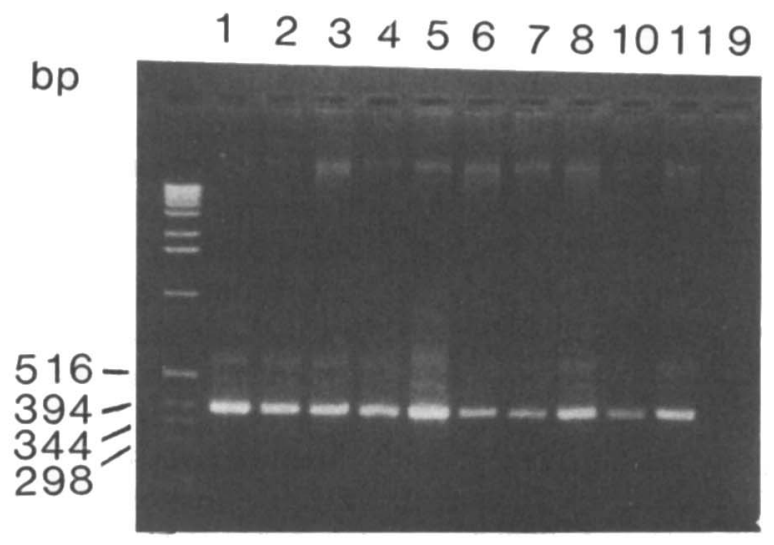

b

1

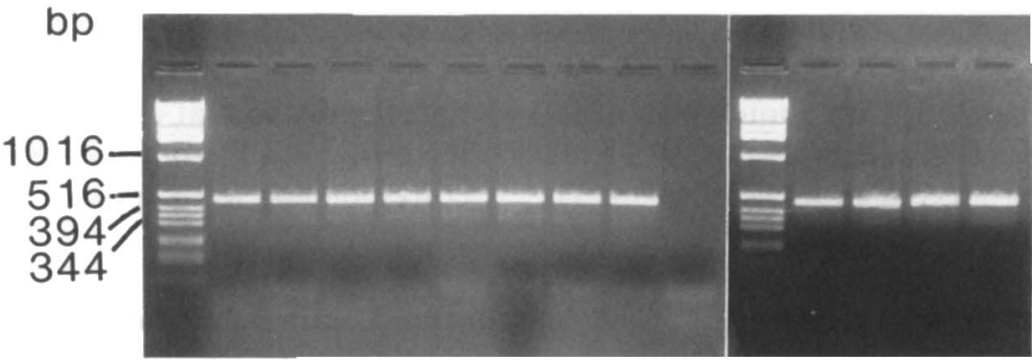

C

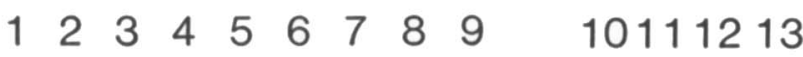

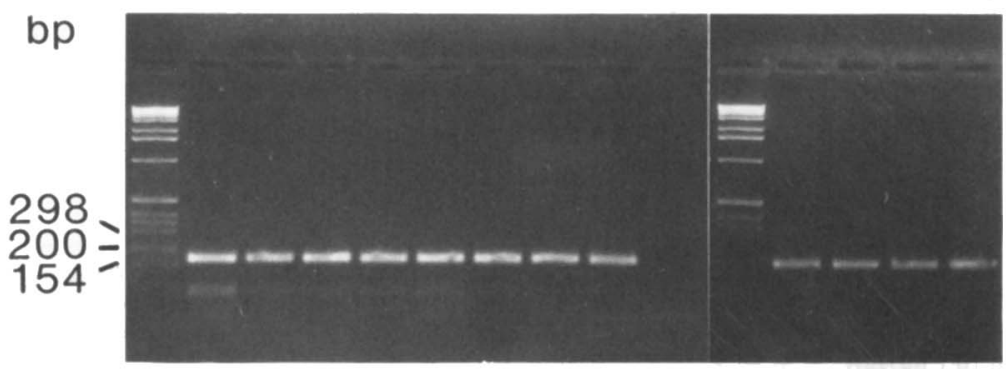

Fig. 2. Amplification of toxin A and B genes by PCR: ethidium bromide-stained agarose gels of PCR products with DNA from $C$. difficile strains (F-prefix indicates serogroup F strain) F-30906 (lane 1), F-25588 (2), F-13631 (3), F-15543 (4), F-20349 (5), F-33179 (6), VPI 10463 (7), CD196 (8), F-35010 (10), F-EX526 (11), F-37101 (12), F-ATCC 43598 (13), C. sordellii IP82 (9). The mol. wt DNA standards are a 1-kb ladder (Gibco-BRL, Paris, France). a and b, Primers derived from C. difficile toxin A gene, P31-P60 (repeat region) and P32-P66 (constant region). The sizes of the PCR products are 381 bp for P31-P60 and 456 bp for P32-P66. c, Primers, P89-P90, derived from the C. difficile toxin B gene. The size of the PCR products corresponds to $177 \mathrm{bp}$.

fig. 2c). Serogroup F strains also contained at least the region corresponding to the repeated portion (primers P31-P60 (fig. 2a) and the $5^{\prime}$ terminal sequence (primers P32-P66) of the toxin A gene, (fig. 2b).$^{10}$ No amplification products were detected with $C$. sordellii strain IP 82 which produces a toxin that is immunologically similar, but distinct from, $C$. difficile toxin A (fig. 2).

Axenic mice were inoculated with strain 33179 ; fig. 3 shows typical results. The animals did not develop diarrhoea, nor did they die. Toxin B was found in their faeces but no toxin A was detected. Two weeks after inoculation with the serogroup F strain, the mice were challenged with the lethal strain VPI 10463. The mice remained healthy, toxin $B$ titres did not increase and toxin A remained undetectable. At days 3 and 6 postchallenge, selective enumeration showed $(/ \mathrm{g}) 10^{8} \mathrm{cfu}$ of serogroup F colonies, but $<10^{6} \mathrm{cfu}$ of serogroup $\mathrm{G}$, i.e., strain VPI 10463. Mice inoculated only with strain VPI 10463 died within 2 days and large quantities of toxins A and B were detected in their faeces (2.8 SEM $0.2 \log _{10} \mathrm{ng} / \mathrm{g}$ toxin $\mathrm{A}$ and 5.7 SEM $0.2 \log _{10}$ titre toxin B). Similar results were obtained with all three sero- 


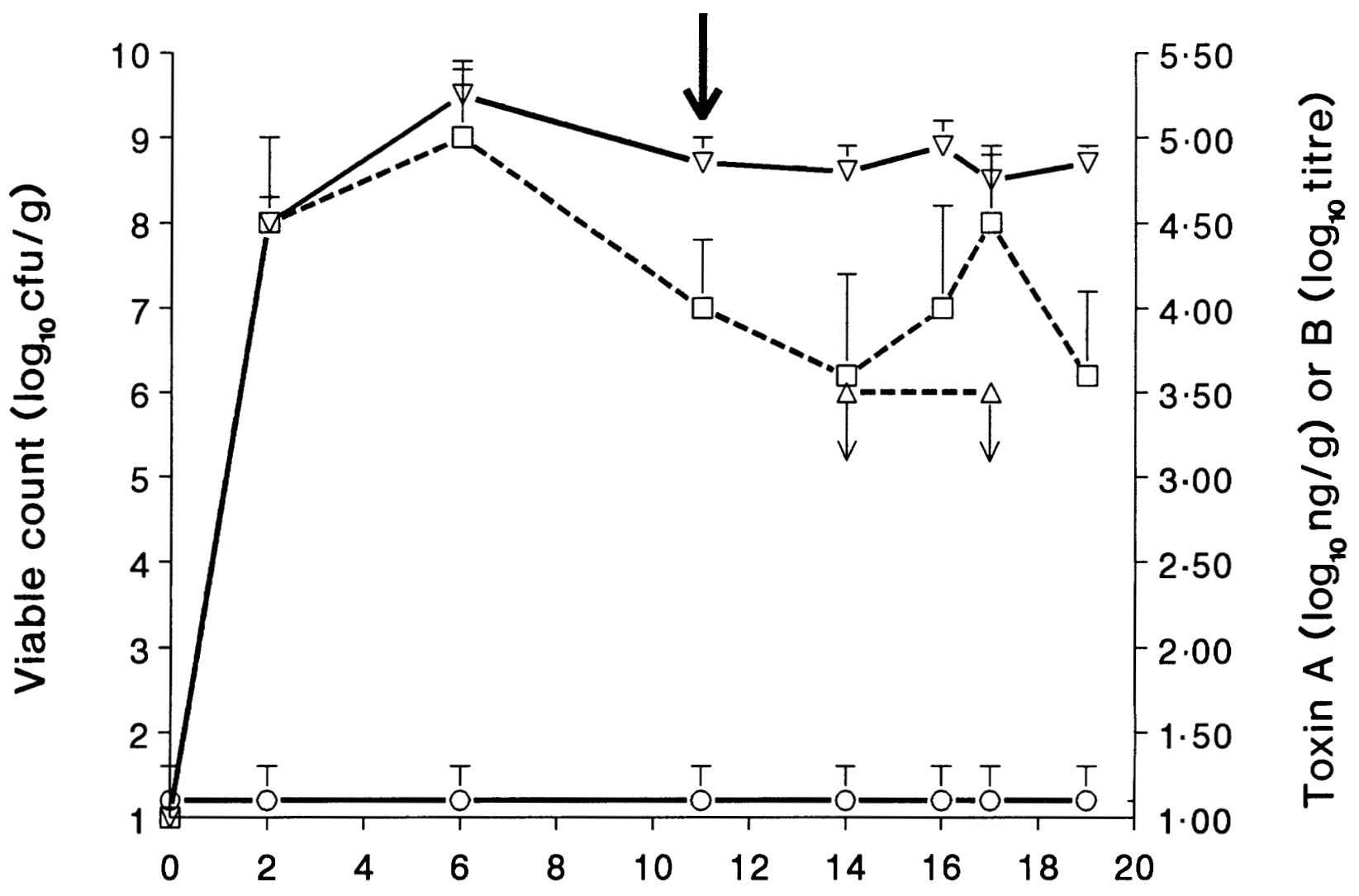

Days after inoculation

Fig. 3. Axenic mice, mono-associated with serogroup $F$ strain 33179 , and challenged with strain VPI 10463 (serogroup G): $\nabla-\nabla$ colony counts serogroup F; $\triangle^{---\triangle} \triangle$ colony counts, serogroup $G ; O--O$ toxin A levels; $\square^{---} \square$ toxin $B$ levels. The arrow corresponds to inoculation of strain VPI 10463 at day 11; bars represent SEM.

group F strains tested (F-35010, F-33179 and ATCC 43598).

\section{Discussion}

C. difficile strains of serogroup $\mathrm{F}$ are often isolated from asymptomatic infants and are known to produce toxin B (cytotoxin).$^{19}$ Our data suggest that serogroup $\mathrm{F}$ strains do not produce toxin $\mathrm{A}$ in vitro. They represent a group of toxin $\mathrm{A}^{-}, \mathrm{B}^{+}$strains. Only one other toxin $\mathrm{A}^{-}, \mathrm{B}^{+}$strain has been described (strain 8864 ) and this was more cytotoxic than strain VPI 10463 , in contrast with serogroup $F$ strains which were all less cytotoxic than strain VPI $10463 .^{11,12}$

PCR amplification indicates that serogroup $F$ strains probably have a toxin B gene homologous to that of the reference strain. ${ }^{28-30}$ The toxin A gene primers revealed that parts of the $5^{\prime}$ terminal sequence and of the repeated region (corresponding to the portion binding to the carbohydrate receptor) are present in serogroup $\mathrm{F}$ strains, despite their failure to produce detectable toxin $\mathrm{A}^{10,31}$ The serogroup $\mathrm{F}$ strains may be real non-producers of toxin A or could produce a modified toxin. MAbs against the antigens corresponding to the repeated sequences do not react with serogroup $F$ strain supernates, suggesting that toxin $A$, if produced, does not contain these epitopes. ${ }^{21}$ Recent work by Borriello et al., ${ }^{12}$ with hybridisation and PCR, suggested that strain 8864 (toxin $\mathrm{A}^{-}, \mathrm{B}^{+}$) did not have the toxin A gene. However, Lyerly et al., with similar techniques but different primers, found that at least a part of the toxin A gene ( $5^{\prime}$ end) was present in this strain. ${ }^{32}$

Cytotoxins produced by serogroup $\mathrm{F}$ strains and strain VPI 10463 were both neutralised by an anti- $C$. difficile and an anti-C. sordellii serum. However, in immunoassays, the cytotoxin of serogroup $F$ strains did not react with two MAbs specific for the toxin B produced by strain VPI 10463. Nevertheless, serogroup F supernates did react with one of the anti- $C$. sordellii LT MAbs. These results suggest that the cytotoxins from serogroup $F$ strains and strain VPI 10463 contain different epitopes. Serogroup F cytotoxin may be more similar to $C$. sordellii cytotoxin than to that of $C$. difficile strain VPI 10463.

Hamsters treated with clindamycin or cefoxitin and challenged with serogroup $\mathrm{F}$ strains did not show any signs of disease. ${ }^{20}$ This was confirmed in gnotobiotic mice mono-associated with serogroup $\mathrm{F}$ strains (F33179 , F-35010 or ATCC 43598). Cytotoxin was produced in vivo but toxin A was not detected. These results are in agreement with studies in vitro.

The protective effect of colonisation with a serogroup $F$ strain to a challenge with a lethal strain, demonstrated here, has not been documented previously. However, these results are in agreement with 
the observation that pre-infection with a non-toxigenic strain may protect against symptomatic infection with a toxigenic strain. ${ }^{33-35}$ No toxin A was detected after the challenge, indicating that strain VPI 10463 did not grow or did not produce toxin $\mathbf{A}$ in these conditions. Cytotoxin, present in mice faeces throughout the experiment, did not increase significantly after the challenge. Furthermore, selective $C$. difficile enumeration showed that serogroup $F$ strains exercised an antagonistic effect against strain VPI 10463 similar to the effect previously described with two VPI clones. ${ }^{34}$ The poor detection limit of the colony serogrouping method prevented firm conclusions as to whether strain VPI 10463 was completely eliminated or merely suppressed to low population levels in the protected mice. These observations may explain why patients carrying serogroup $\mathrm{F}$ strains are asymptomatic.

Several reports have shown that asymptomatic infants may carry $C$. difficile strains that produce toxin $\mathrm{A}$ in vitro. Whether toxin $\mathrm{A}$ is produced in vivo or not, is not clearly established because toxin A was rarely quantified in infant stool. However, a previous study ${ }^{36}$ reported that toxin $\mathrm{A}$ may be detected in stools of asymptomatic children. Diarrhoea was observed in one child with the highest levels of toxin in stools. ${ }^{36}$ The serogroup F strains were more frequently isolated from infants who can harbour cytotoxin in their stools without showing any pathological signs. ${ }^{19}$ The presence of toxin A was not investigated, but, on the basis of our results with serogroup $F$ strains, such infants probably do not have toxin A in their stools.

In conclusion, our data suggest that the $\mathrm{A}^{-}, \mathrm{B}^{+}$ phenotype is not unique to $C$. difficile strain 8864 , but is common to serogroup F strains, at least for those strains studied. Furthermore, the toxin B produced by serogroup $\mathrm{F}$ strains seemed to be more similar to $C$. sordellii $\mathrm{LT}$ than to the toxin $\mathrm{B}$ produced by $C$. difficile VPI 10463

We thank P. Rapine and V. Guyot for their technical assistance.

\section{References}

1. Bartlett JG, Moon N, Chang TW, Taylor N, Onderdonk AB Role of Clostridium difficile in antibiotic-associated pseudomembranous colitis. Gastroenterology 1978; 75: 778-782

2. George WL, Symonds JM, Dimock F et al. Identification of Clostridium difficile as a cause of pseudomembranous colitis. BMJ 1978; 1 : 695 .

3. Banno $\mathrm{Y}$, Kobayashi T, Kono H, Watanabe K, Ueno $\mathrm{K}$, Nozawa Y. Biochemical characterization and biologic actions of two toxins (D-1 and D-2) from Clostridium difficile. Rev Infect Dis 1984; 6 Suppl: S11-S20.

4. Lyerly DM, Lockwood DE, Richardson SH, Wilkins TD. Biological activities of toxins A and B of Clostridium difficile. Infect Immun 1982; 35: 1147-1150.

5. Sullivan NM, Pellett $S$, Wilkins TD. Purification and characterization of toxins A and B of Clostridium difficile. Infect Immun 1982; 35: 1032-1040.

6. Taylor NS, Thorne GM, Barlett JG. Comparison of two toxins produced by Clostridium difficile. Infect Immun 1981; 34 : 1036-1043.

7. Vernet A, Corthier G, Dubos-Ramaré F, Parodi AL. Relationships between levels of Clostridium difficile toxin A and toxin B and cecal lesions in gnotobiotic mice. Infect Immun $1989 ; 57: 2123-2127$

8. Wren B, Heard SR, Tabaqchali S. Association between production of toxins $\mathrm{A}$ and $\mathrm{B}$ and types of Clostridium difficile $J$ Clin Pathol 1987; 40: 1397-1401.

9. Barroso LA, Wang SZ, Phelps CJ, Johnson JL, Wilkins TD. Nucleotide sequence of Clostridium difficile toxin B gene. Nucleic Acids Res 1990; 18: 4004.

10. Dove $\mathrm{CH}$, Wang S-Z. Price SB et al. Molecular characterization of the Clostridium difficile toxin A gene. Infect Immun 1990; 58: $480-488$

11. Torres JF. Purification and characterisation and toxin B from a strain of Clostridium difficile that does not produce toxin A $J$ Med Microbiol 1991; 35: 40-44.

12. Borriello SP, Wren BW, Hyde S et al. Molecular, immunological, and biological characterization of a toxin Anegative, toxin B-positive strain of Clostridium difficile. Infect Immun 1992; 60: 4192-4199.

13. Delmée M. Avesani V, Ernest I, Surleraux M. Detection of specific antigens for ten serogroups of Clostridium difficile. Mol Cell Probes 1990; 4: 1-10.

14. Delmée M, Homel M, Wauters G. Serogrouping of Clostridium difficile strains by slide agglutination. J Clin Microbiol $1985 ; 21: 323-327$.
15. Delmée M, Laroche Y, Avesani V, Cornelis G. Comparison of serogrouping and polyacrylamide gel electrophoresis for typing Clostridium difficile. J Clin Microbiol 1986; 24 : 991-994.

16. Tabaqchali S, Holland D, O'Farrell S, Silman R. Typing scheme for Clostridium difficile: its application in clinical and epidemiological studies. Lancet 1984; 1: 935-938.

17. Tabaqchali S. Epidemiologic markers of Clostridium difficile. Rev Infect Dis 1990; 12 Suppl 2: S192-S199.

18. Toma S, Lesiak G, Magus M, Lo H-L, Delmée M. Serotyping of Clostridium difficile. J Clin Microbiol 1988; 26: 426-428.

19. Delmée M, Verellen G, Avesani V, Francois G. Clostridium difficile in neonates: serogrouping and epidemiology. Eur $J$ Pediatr 1988; 147: 36-40.

20. Delmée M, Avesani V. Virulence of 10 serogroups of Clostridium difficile in hamsters. J Med Microbiol 1990; 33 85-90.

21. Corthier G, Muller MC, Wilkins TD, Lyerly D, L'Haridon R. Protection against experimental pseudomembranous colitis in gnotobiotic mice by use of monoclonal antibodies against Clostridium difficile toxin A. Infect Immun 1991; 59: 1192-1195.

22. Depitre C, L'Haridon RM, Lyerly DM et al. Production of monoclonal antibodies against Clostridium difficile cytotoxin using ImmunoSorbent Binding BioAssay procedure. Toxicon 1992 (in press).

23. Mahé S, Corthier G, Dubos F. Effect of various diets on toxin production by two strains of Clostridium difficile in gnotobiotic mice. Infect Immun 1987; 55: 1801-1805.

24. Popoff MR. Purification and characterization of Clostridium sordellii lethal toxin and cross-reactivity with Clostridium difficile cytotoxin. Infect Immun 1987; 55: 35-43.

25. Dipersio JR, Varga FJ, Conwell DL, Kraft JA, Kozak KJ, Willis DH. Development of a rapid Enzyme Immunoassay for Clostridium difficile toxin $\mathrm{A}$ and its use in the diagnosis of C. difficile-associated disease. J Clin Microbiol 1991; 29 2724-2730.

26. Popoff MR, Guillou J-P, Carlier J-P. Taxonomic position of lecithinase-negative strains of Clostridium sordellii. J Gen Microbiol 1985; 131: 1697-1703.

27. Sauerborn M, Von Eichel-Streiber C. Nucleotide sequence of Clostridium difficile toxin A. Nucleic Acids Res 1990; 18: 1629-1630.

28. Kato $\mathrm{N}$, Ou CY, Kato $\mathrm{H}$ et al. Identification of toxigenic Clostridium difficile by the polymerase chain reaction. $J$ Clin Microbiol 1991; 29: 33-37.

29. McMillin DE, Muldrow LL, Leggette SJ, Abdulahi Y, Ekanemesang UM. Molecular screening of Clostridium difficile 
toxins A and B genetic determinants and identification of mutant strains. FEMS Microbiol Lett 1991; 62: 75-80.

30. Wren BW, Clayton CL, Tabaqchali S. Nucleotide sequence of Clostridium difficile toxin A gene fragment and detection of toxigenic strains by polymerase chain reaction. FEMS Microbiol Lett 1990; 15: 1-6.

31. Lyerly DM, Johnson JL, Wilkins TD. Characterization of the binding portion of Clostridium difficile toxin A. Microecol Ther 1989; 19: 233-237.

32. Lyerly DM, Barroso LA, Wilkins TD, Depitre C, Corthier G. Characterization of a toxin A-negative, toxin B-positive strain of $C$. difficile. Infect Immun 1992; 60: 4633-4639.
33. Borriello SP, Barclay FE. Protection of hamsters against Clostridium difficile ileocaecitis by prior colonisation with non-pathogenic strains. J Med Microbiol 1985; 19: 339-350.

34. Corthier G, Muller MC. Emergence in gnotobiotic mice of nontoxinogenic clones of Clostridium difficile from a toxinogenic one. Infect Immun 1988; 56: 1500-1504.

35. Wilson KH, Sheagren JN. Antagonism of toxigenic Clostridium difficile by nontoxigenic $C$. difficile. J Infect Dis $1983 ; 147$ : 733-736.

36. Libby JM, Donta ST, Wilkins TD. Clostridium difficile toxin A in infants. $J$ Infect Dis 1983; 148: 606. 